\title{
NOTE
}

\section{Influence of photoperiod on pigmentation and metabolic efficiency of the marine aerobic anoxygenic photosynthetic bacterium Erythrobacter longus Strain NJ3Y}

\author{
Michael J. Cooney ${ }^{1}$, Wayne A. Johnston ${ }^{1}$, Silke Pohl ${ }^{1}{ }$, Robert R. Bidigare ${ }^{2, *}$ \\ ${ }^{1}$ Hawaii Natural Energy Institute, and ${ }^{2}$ Department of Oceanography, 1680 East West Road, University of Hawaii, Honolulu, \\ Hawaii 96822, USA
}

\begin{abstract}
The marine photoheterotroph Erythrobacter longus Strain NJ3Y was grown in continuous culture under variable light:dark (L:D) regimes of 24:0, 12:12 and 0:24 h to examine the influence of photoperiod on pigmentation and metabolic efficiency. Average carbon mass balances for each light regime closed to within $5 \%$, giving confidence in the measured variables as well as calculations of physiological parameters. Significant differences in photosynthetic pigmentation were observed for the experimental light treatments, with highest and lowest pigment concentrations measured in the 0:24 and 24:0 h L:D regimes, respectively, indicating that the photosynthetic pigments of $E$. longus Strain NJ3Y are preferentially synthesized in the dark. These differences are consistent with the strategy that photosynthetic pigments are produced during periods of darkness, for use in energy harvesting during subsequent light periods. In contrast, concentrations of the photoprotective pigment caloxanthin sulfate were highest for cells grown under a 12:12 h L:D cycle, indicating that this carotenoid is synthesized in the light and the dark. It is concluded that the 12:12 h L:D regime provides the maximum opportunity for $E$. longus Strain NJ3Y to derive a metabolic advantage from light availability (i.e. by enabling it to both synthesize and utilize its light harvesting apparatus). The corresponding carbon-specific glucose uptake rate was $\sim 30 \%$ higher than that measured for the 0:24 and 24:0 $\mathrm{h} \mathrm{L}: \mathrm{D}$ regimes. It is hypothesized that light-stimulated rates of dissolved organic carbon uptake by bacteriochlorophyll a containing bacteria confer a slight competitive advantage over bacteria that lack this photosynthetic machinery. Lowest glucose-specific biomass yields $\left(Y_{\mathrm{x} / \mathrm{s}} \mathrm{g}\right.$ dry cell $\mathrm{wt}^{-1}$ glucose) were observed for the 12:12 $\mathrm{h} \mathrm{L}$ :D treatment, suggesting that under the culture conditions used in this study, photosynthesis does not contribute significantly to the growth of E. longus Strain NJ3Y.
\end{abstract}

KEY WORDS: Erythrobacter $\cdot$ Photoheterotrophy $\cdot$ Bacteriochlorophyll $a \cdot$ Carotenoids

\section{INTRODUCTION}

Recent advances in molecular genetic techniques and optical instrumentation have revealed the widespread distribution of diverse assemblages of marine (obligate) heterotrophic bacteria that possess lightbased metabolisms for the production of ATP (Rathgeber et al. 2004, DeLong \& Karl 2005, Giovannoni \&
Sting 2005). These aerobic microbes have been identified in coastal and open oceanic waters, and include proteorhodopsin (PR) containing $\alpha$ - and $\gamma$-proteobacteria (Béjà et al. 2000, 2001, Morris et al. 2002, Venter et al. 2004, Cottrell et al. 2006, DeLong et al. 2006) and bacteriochlorophyll a (Bchl a) containing $\alpha$-, $\beta$ - and $\gamma$ proteobacteria (Harashima et al. 1978, Shiba et al. 1979, 1991, Yurkov \& Beatty 1998, Kolber et al. 2000, 
2001, Béjà et al. 2002, de la Torre et al. 2003, Koblížek et al. 2003, Jiao et al. 2005, Schwalbach \& Fuhrman 2005, Cottrell et al. 2006). While the distribution of PR containing bacteria is apparently restricted to marine waters, Bchl a containing bacteria are also found in freshwater habitats (Yurkov \& Beatty 1998, Waidner \& Kirchman 2005). It should be noted that, in most cases, the presence of photoheterotrophic bacteria (PHB) in natural waters has been established using fluorescence in situ hybridization (FISH) probes (PR containing bacteria; Morris et al. 2002) and infrared epifluorescence microscopy (Bchl a containing bacteria; Kolber et al. 2001), and screening environmental DNA samples for the presence of diagnostic genes (e.g. 16S rRNA, RNA polymerase, PR, and pufM gene sequences; Béjà et al. 2002, de la Torre et al. 2003). Fortunately, several representative marine PHB Strains (Pelagibacter ubique, Rappé et al. 2002; Erythrobacter longus, Koblížek et al. 2003) have been cultured and are available for genomic sequencing (Giovannoni et al. 2005a) and physiological study (Kobližek et al. 2003, Giovannoni et al. 2005b, Johnston et al. 2005).

The ubiquitous nature of PHB distributions in the world ocean has led to the speculation that these microbes play a significant role in global carbon cycling (Fenchel 2001, Karl 2002). While members of the SAR11 clade of PR containing bacteria (e.g. Pelagibacter ubique) have been shown to account for a significant fraction of oceanic bacteria (Morris et al. 2002), estimates of pigment biomass contributions by Bchl a containing bacteria (hereafter referred to as aerobic anoxygenic photoheterotrophs, AAPs) are highly variable and the subject of current controversy (Kolber et al. 2001, Goericke 2002, Karl 2002). Schwalbach \& Fuhrman (2005) suggested that early reports of AAP abundance based on infrared epifluorescence microscopy may have been overestimates due to the overlap between chlorophyll a (cyanobacteria) and Bchl a (AAPs) autofluorescence bands at wavelengths exceeding $850 \mathrm{~nm}$. Since these initial reports, additional observations made using multiple methods (i.e. 'corrected' direct counts and quantitative polymerase chain reaction) confirm that AAP abundances are spatially and temporally variable and range from not detectable to $\sim 20 \%$ of total bacteria counts or DNA content (Schwalbach \& Fuhrman 2005, Cottrell et al. 2006). An examination of data available to date suggests that AAP abundances are higher in the Atlantic Ocean, in eutrophic environments (estuarine and coastal waters) and in the euphotic zone than in the Pacific Ocean, oligotrophic waters and below the euphotic zone (Schwalbach \& Fuhrman 2005, Cottrell et al. 2006). Jiao et al. (2005) reported that highest AAP abundances occur in those marine habitats that have elevated dissolved organic carbon (DOC) concentrations (e.g. conti- nental shelf and estuarine waters). The empirical observations summarized above call into question the notion that Bchl a mediated carbon fixation by AAPs confers a selective advantage over 'purely' heterotrophic bacteria in oligotrophic environments where DOC concentrations are low (Beatty 2002).

Erythrobacter spp.-related AAPs are obligate heterotrophs, catabolize a wide range of DOC substrates using $\mathrm{O}_{2}$-dependent respiration, and have the ability to supplement their nutrition via anoxygenic photosynthesis (Koblížek et al. 2003). Energy for ATP production and carbon fixation is provided through light energy absorbed by light harvesting pigments (Bchl $a$, zeaxanthin and bacteriorubixanthinal, Fig. 1). In addition, these APPs possess high cellular concentrations of carotenoid sulfates (e.g. caloxanthin sulfate and erythroxanthin sulfate) that have a photoprotective function. Physiological measurements of E. longus Strain NAP1 indicate that $\sim 20 \%$ of its cellular energy requirement can be provided by photosynthetic electron transport (Kolber et al. 2001). Yurkov \& van Gemerden (1993) grew the freshwater AAP Erythromicrobium hydrolyticum in continuous culture on a variable light:dark (L:D) cycle and measured a $10 \%$ increase in protein content during the first $5 \mathrm{~h}$ of illumination relative to that observed during the dark phase. In contrast, light manipulation experiments and environmental DNA sequencing of seawater samples collected in mesotrophic and oligotrophic waters off California revealed that the Roseobacter-related phylogenetic group exhibited a strong preference for dark treatments (Schwalbach et al. 2005). However, these authors suggested that this observation may be a consequence of increased phytoplankton decay products in dark relative to light treatments.

In a previous paper we presented a carbon mass balance methodology employing minimal measurements that was applied to pigmented heterotrophic and photoheterotrophic marine bacteria grown in continuous culture on a 12:12 h L:D cycle (Johnston et al. 2005). The continuous culture system described therein, coupled with carbon mass balancing methodology, proved useful for characterizing and comparing the metabolic profiles of heterotrophic and photoherotrophic marine bacteria. In the present study, the same methodology was used to investigate the dependence of the growth physiology parameters of Erythrobacter longus Strain NJ3Y on photoperiod. This work complements the previous continuous culture measurements performed with the freshwater AAP Erythromicrobium hydrolyticum (Yurkov \& van Gemerden 1993) and was designed to quantify the influences of photoperiod on photosynthetic pigmentation, glucose-specific biomass yields and carbon-specific glucose uptake rates of E. longus Strain NJ3Y. 


\section{MATERIALS AND METHODS}

Growth medium. A modified $f / 2$ medium was prepared with $0.2 \mu \mathrm{m}$-filtered seawater containing $10 \mathrm{mM}$ $\mathrm{NH}_{4} \mathrm{Cl}, 3.0 \mathrm{~g} \mathrm{l}^{-1}$ glucose, $0.21 \mathrm{mM} \mathrm{NaH}_{2} \mathrm{PO}_{4}$, and $2 \mathrm{ml}$ $\mathrm{l}^{-1}$ each of a vitamin (cyanocobalamin, $0.0005 \mathrm{~g} \mathrm{l}^{-1}$; thiamine $\mathrm{HCl}, 0.1 \mathrm{~g} \mathrm{l}^{-1}$; biotin, $0.0005 \mathrm{~g} \mathrm{l}^{-1}$ ) and a trace element solution (EDTA, $4.360 \mathrm{~g} \mathrm{l}^{-1} ; \mathrm{FeCl}_{3} \cdot 6 \mathrm{H}_{2} \mathrm{O}$, $3.150 \mathrm{~g} \mathrm{l}^{-1} ; \mathrm{CuSO}_{4} \cdot 5 \mathrm{H}_{2} \mathrm{O}, 0.010 \mathrm{~g} \mathrm{l}^{-1} ; \mathrm{ZnSO}_{4} \cdot 7 \mathrm{H}_{2} \mathrm{O}$,

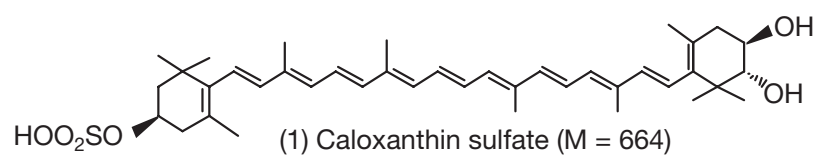

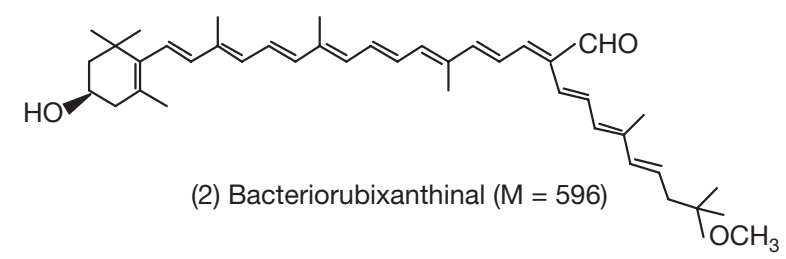

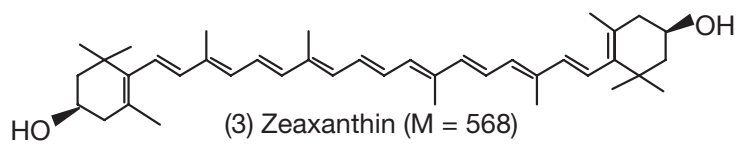

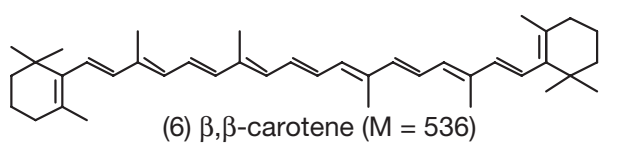
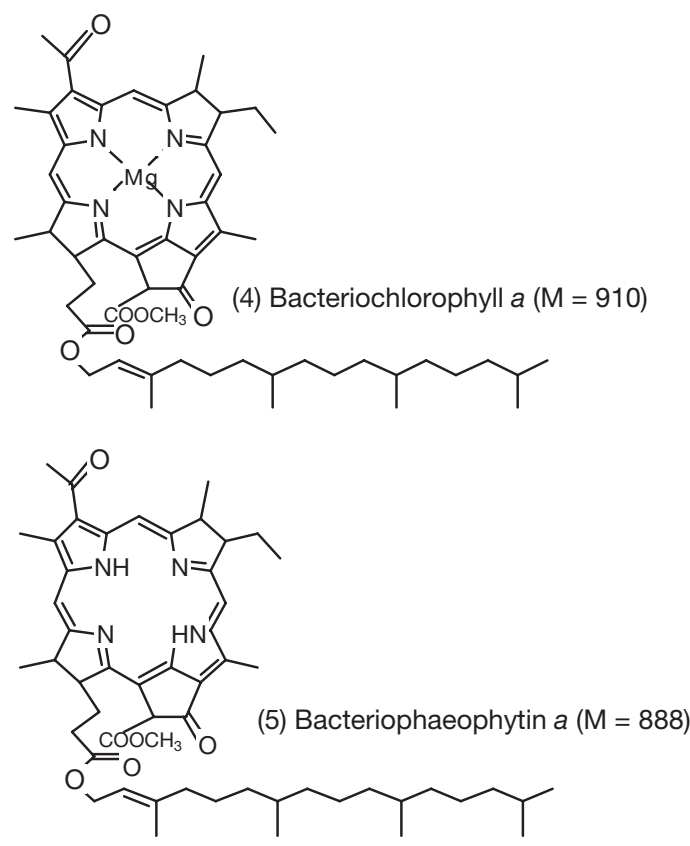

Fig. 1. Erythrobacter longus Strain NJ3Y. Structures and molecular weights $(\mathrm{M})$ of chlorophyll and selected carotenoid pigments identified
$0.022 \mathrm{~g} \mathrm{l}^{-1} ; \mathrm{CoCl}_{2} \cdot 6 \mathrm{H}_{2} \mathrm{O}, 0.010 \mathrm{~g} \mathrm{l}^{-1} ; \mathrm{MnCl}_{2} \cdot 4 \mathrm{H}_{2} \mathrm{O}$ ， $\left.0.180 \mathrm{~g} \mathrm{l}^{-1} ; \mathrm{Na}_{2} \mathrm{MoO}_{4} \cdot 2 \mathrm{H}_{2} \mathrm{O}, 0.006 \mathrm{~g} \mathrm{l}^{-1}\right)$.

Cultivation and sample collection. Complete details of the experimental procedures can be found in Johnston et al. (2005). The marine photoheterotrophic bacterium Erythrobacter longus Strain NJ3Y (Koblížek et al. 2003) was obtained as a generous gift from P. G. Falkowski and Z. S. Kolber (Rutgers University). The continuous culture system was equipped with a $1.5 \mathrm{l}$ spinner flask (B. Braun) that was inoculated with $50 \mathrm{ml}$ of culture. The bioreactor was initially operated in batch culture mode for 4 to $6 \mathrm{~d}$ at a temperature of $25^{\circ} \mathrm{C}$ and mixing rate of $180 \mathrm{rpm}$. During continuous culture, the bioreactor temperature, dissolved oxygen concentration and $\mathrm{pH}$ were maintained at $25^{\circ} \mathrm{C},>50 \%$ saturation and 7.8, respectively. An incident PAR irradiance of $90 \pm 10 \mu \mathrm{E} \mathrm{m}^{-2} \mathrm{~s}^{-1}$ was provided by four $20 \mathrm{~W}$ incandescent tube-lights on both sides of the reactor that were controlled with a self-regulating timer. To maintain a constant reactor volume, spent medium was pumped from the reactor through an exit tube placed directly above the liquid surface at a height yielding a constant reactor volume $(1.2 \mathrm{l})$. Inlet and outlet flow rates were quantified by placing both the inlet feed and spent medium reservoirs on top loading balances and measuring the weight loss or gain over defined periods of time (18 to $24 \mathrm{~h}$ ). Cultures were maintained at a given set of experimental conditions until a steadystate growth rate was achieved.

Samples (4.5 ml each) were collected aseptically for biochemical analysis. From each sample, $0.5 \mathrm{ml}$ was taken, diluted to $1 \mathrm{ml}$ by the addition of an equal volume of $0.2 \mu \mathrm{m}$ filtered seawater, for the measurement of optical density at $650 \mathrm{~nm}\left(\mathrm{OD}_{650}\right)$. The remaining sample $(4 \mathrm{ml})$ was used for the determination of particulate organic carbon (POC), pigment and carbon: hydrogen:nitrogen $(\mathrm{CHN})$ ratios. For pigment and CHN analysis, two $1 \mathrm{ml}$ and two $0.5 \mathrm{ml}$ samples, respectively, were vacuum filtered onto $25 \mathrm{~mm}$ GF/F filters and frozen under liquid nitrogen prior to analysis. The resulting filtrates were frozen $\left(-20^{\circ} \mathrm{C}\right)$ for the later determination of DOC and glucose concentrations $\left(C_{\text {glu }} \mathrm{g} \mathrm{l}^{-1}\right)$.

Oxygen and carbon dioxide concentrations in the gas stream exiting the bioreactor were quantified by passage through a paramagnetic/infrared gas analyzer (Siemens). The respiratory quotient (RQ) was calculated using a generalized degree of reduction balance on glucose consumption, as adapted from Nielsen \& Villadsen (1994). Mass balance calculations were performed using Eq. (1) as detailed in Johnston et al. (2005):

$$
C_{\mathrm{DOC}}^{\text {in }} \times F^{\text {in }}+C_{\text {air }}^{\text {in }} \times M^{\text {in }}=C_{\mathrm{DOC}} \times F^{\text {out }}+C_{\text {air }} \times M^{\text {out }}+C_{\mathrm{x}} \times F^{\text {out }}
$$


where $F^{\text {in }}\left(\mathrm{l} \mathrm{h}^{-1}\right)$ is the inlet flow rate of liquid phase feed medium, $F^{\text {out }}\left(\mathrm{l} \mathrm{h}^{-1}\right)$ is the outlet flow rate of liquid phase medium, $M^{\text {in }}\left(\mathrm{l} \mathrm{h}^{-1}\right)$ is the flow rate of inlet gas (air) entering the bioreactor, $M^{\text {out }}\left(\mathrm{l} \mathrm{h}^{-1}\right)$ is the flow rate of exit gas leaving the bioreactor, $C_{\text {air }}^{\text {in }}\left(\mathrm{g} \mathrm{l}^{-1}\right)$ is the carbon dioxide carbon concentration in the inlet air, $C_{\text {glu }}^{\text {in }}$ $\left(\mathrm{g} \mathrm{l}^{-1}\right)$ is the glucose carbon in the inlet feed medium, $C_{\text {DOC }}^{\text {in }}\left(\mathrm{g} \mathrm{l}^{-1}\right)$ is the DOC in the inlet feed medium (i.e. seawater), $C_{\text {DOC }}\left(\mathrm{g} \mathrm{l}^{-1}\right)$ is the amount of DOC $\mathrm{l}^{-1}$ in the growth chamber, and $C_{\mathrm{x}}\left(\mathrm{g} \mathrm{l}^{-1}\right)$ is the amount of biomass carbon $\mathrm{l}^{-1}$ in the growth chamber.

Analytical measurements. Complete details of all analytical procedures have been published elsewhere (Kobližek et al. 2003, Johnston et al. 2005). Primary biomass quantification was based on POC content determined via CHN analysis. In addition, dry cell weight (dcw) quantification of cultivation samples was conducted using optical density (OD) measurements at $650 \mathrm{~nm}$. Calibration of the dcw to the OD via dilution series was conducted for each experiment (data not shown). To eliminate the effect of salt residue from seawater on the dcw assay, 3 rinses of ammonium formate on the filter were applied. Glucose concentrations were determined by enzymatic assay as per manufacturer's instructions (Boehringer) and the protocols defined in Johnston et al. (2005). Seawater interference was excluded from analyses via a $1.0 \mathrm{~g} \mathrm{l}^{-1}$ glucose standard prepared in filtered seawater (Johnston et al. 2005). The measurement of DOC was performed using the high temperature catalytic oxidation method (Church et al. 2002). CHN analyses were carried out using a Perkin-Elmer 2400 elemental analyzer.

Pigments were analyzed using highperformance liquid chromatography (HPLC) and liquid chromatography/ mass spectrometry (LC/MS) following the methods described in Koblížek et al. (2003). Eluting pigments were identified on the basis of retention time, on-line diode array spectroscopy, co-injection analysis using authentic standards (if available), and LC/MS analysis. Bchl $a$, bacteriopheophytin $a$, zeaxanthin, and $\beta, \beta$-carotene were quantified using commercially available standards as described by Bidigare et al. (2005). Caloxanthin sulfate is structurally related to zeaxanthin and was quantified with the zeaxanthin response factor. Total carotenoid concentrations were determined spectrophotometrically using an absorption coefficient of $\varepsilon_{460}=$ $128 \mathrm{mM}^{-1} \mathrm{~cm}^{-1}$ (Yurkov et al. 1993).
Bacteriorubixanthinal concentrations were estimated as the difference between total carotenoid concentration and the summation of individual HPLC-determined carotenoid concentrations (i.e. caloxanthin sulfate plus zeaxanthin plus $\beta, \beta$-carotene). The total photosynthetic pigment (TPP) concentration is defined as the total pigment concentration minus the caloxanthin sulfate concentration.

\section{RESULTS}

Average carbon mass balances for each light regime closed to within $5 \%$, giving confidence in the measured variables as well as calculations of physiological parameters (Tables $1 \& 2$ ). Mean concentrations $\left(\mathrm{g} \mathrm{l}^{-1}\right)$ of biomass carbon $\left(C_{\mathrm{x}}\right)$, nitrogen $\left(N_{\mathrm{x}}\right)$ and dry cell weight $(X)$ in the growth chamber were different for each of the 3 light treatments, with highest, intermediate and lowest values for the 0:24, 12:12 and 24:0 h L:D regimes, respectively (Tukey's pairwise comparison, family error rate $=0.05$ ). The biomass carbon to nitrogen ratios $(\mathrm{C}: \mathrm{N})$ ranged from 8.12 to $8.72\left(\mathrm{~g} \mathrm{~g} \mathrm{~g}^{-1}\right)$ and were not statistically different (1-way ANOVA, $p=0.071$ ). The glucose-specific biomass yields $\left(Y_{\mathrm{x} / \mathrm{s}} \mathrm{g}\right.$ dcw $\mathrm{g}^{-1}$ glucose $)$ were greater for the 24:0 and 0:24 h L:D treatments, while the glucose carbon uptake normalized to carbon biomass (CSPGUR, $\mathrm{g} \mathrm{g}^{-1} \mathrm{~h}^{-1}$ ) was higher for Erythrobacter longus Strain NJ3Y grown on a 12:12 h L:D cycle (Tukey's pairwise comparison, family error rate $=0.05$ ). This latter result follows the observation that the residual glucose concentration in the growth chamber was higher for all

Table 1. Erythrobacter longus Strain NJ3Y. Average carbon mass balance and biomass parameters for continuous cultures maintained on light:dark (L:D) cycles of 12:12, 24:0 and 0:24 h. Constants: $M^{\text {in }}=M^{\text {out }}=5.91 \mathrm{~g} \mathrm{l}^{-1}, C_{\text {air }}^{\text {in }}=0.00015$ $\mathrm{g} \mathrm{l}^{-1} ; C_{\text {DOC }}^{\text {in }}=1.349 \mathrm{~g} \mathrm{l}^{-1} ; C_{\text {glu }}^{\text {in }}=3.16 \mathrm{~g} \mathrm{l}^{-1}(\mathrm{~L}: \mathrm{D}=12: 12 \mathrm{~h}), 3.35 \mathrm{~g} \mathrm{l}^{-1}(\mathrm{~L}: \mathrm{D}=24: 0 \mathrm{~h})$, and $3.32 \mathrm{~g} \mathrm{l}^{-1}(\mathrm{~L}: \mathrm{D}=0: 24 \mathrm{~h})$. For explanation of terms see 'Materials and methods; Cultivation and sample collection'

\begin{tabular}{|c|c|c|c|c|c|c|c|}
\hline \multirow{2}{*}{ Term } & \multirow{2}{*}{ Units } & \multicolumn{2}{|c|}{$-12: 12 \mathrm{~h}-$} & \multicolumn{2}{|c|}{$-24: 0 \mathrm{~h}-$} & \multicolumn{2}{|c|}{$0: 24 \mathrm{~h}-$} \\
\hline & & Mean & SE & Mean & $\mathrm{SE}$ & Mean & $\mathrm{SE}$ \\
\hline$F^{\text {in }}$ & $1 \mathrm{~h}^{-1}$ & 0.0104 & $<0.0001$ & 0.0091 & $<0.0001$ & 0.0109 & $<0.0001$ \\
\hline$F^{\text {out }}$ & $1 \mathrm{~h}^{-1}$ & 0.0104 & $<0.0001$ & 0.0090 & $<0.0001$ & 0.0108 & $<0.0001$ \\
\hline $\mathrm{CO}_{2}$ & $\%$ & 0.168 & 0.009 & 0.113 & 0.002 & 0.163 & 0.012 \\
\hline$C_{\text {air }}$ & $g l^{-1}$ & 0.0008 & $<0.0001$ & 0.0006 & $<0.0001$ & 0.0008 & 0.0001 \\
\hline$C_{\mathrm{DOC}}$ & $g l^{-1}$ & 0.514 & 0.037 & 0.771 & 0.025 & 0.547 & 0.030 \\
\hline$C_{\mathrm{glu}}$ & $g \mathrm{l}^{-1}$ & 0.386 & 0.020 & 0.710 & 0.014 & 0.510 & 0.026 \\
\hline$C_{\mathrm{x}}$ & $\mathrm{g} \mathrm{l}^{-1}$ & 0.381 & 0.030 & 0.323 & 0.020 & 0.451 & 0.012 \\
\hline$N_{\mathrm{x}}$ & $\mathrm{g} \mathrm{l}^{-1}$ & 0.046 & 0.004 & 0.037 & 0.002 & 0.056 & $<0.001$ \\
\hline$X$ & $\mathrm{~g} \mathrm{l}^{-1}$ & 0.76 & 0.06 & 0.64 & 0.04 & 0.90 & 0.02 \\
\hline C:N & $\mathrm{g} \mathrm{g}^{-1}$ & 8.24 & 0.32 & 8.72 & 0.68 & 8.12 & 0.25 \\
\hline$\Sigma C^{\text {in }}$ & $\mathrm{g} \mathrm{h}^{-1}$ & 0.0150 & $<0.0001$ & 0.0123 & $<0.0001$ & 0.0155 & $<0.0001$ \\
\hline$\Sigma C^{\text {out }}$ & $\mathrm{g} \mathrm{h}^{-1}$ & 0.0143 & 0.0002 & 0.0132 & 0.0003 & 0.0155 & 0.0003 \\
\hline
\end{tabular}


Table 2. Erythrobacter longus Strain NJ3Y. Physiological parameters and carbon-specific pigment concentrations (in growth chamber) for continuous cultures maintained on light:dark cycles of 12:12, 24:0 and 0:24 h. $Y_{\mathrm{x} / \mathrm{s}}=$ glucosespecific biomass yield, CSPGUR = glucose carbon uptake normalized to carbon biomass, Calox $=$ caloxanthin sulfate, Zeax $=$ zeaxanthin, Bchl $a=$ bacteriochlorophyll $a$, Bphea $=$ bacteriophaeophytin $a$, Bcar $=\beta, \beta$-carotene and Bact $=$ bacteriorubixanthinal; nd: not detected

\begin{tabular}{|lccccccc|}
\hline \multirow{2}{*}{ Term } & \multirow{2}{*}{ Units } & \multicolumn{2}{c}{$12: 12 \mathrm{~h}$} & \multicolumn{2}{c}{$24: 0 \mathrm{~h}$} & \multicolumn{2}{c|}{$0: 24 \mathrm{~h}$} \\
& & Mean & SE & Mean & SE & Mean & SE \\
\hline$Y_{\mathrm{x} / \mathrm{s}}$ & $\mathrm{g} \mathrm{g}^{-1}$ & 0.35 & 0.02 & 0.41 & 0.03 & 0.44 & 0.02 \\
$\mathrm{CSPGUR}$ & $\mathrm{g} \mathrm{g}^{-1} \mathrm{~h}^{-1}$ & 0.0201 & 0.0013 & 0.0149 & 0.0011 & 0.0163 & 0.0004 \\
$\mathrm{RQ}$ & $\mathrm{mol} \mathrm{mol}^{-1}$ & 1.04 & $<0.01$ & 1.06 & 0.01 & 1.08 & 0.01 \\
Calox & $\mathrm{nmol} \mathrm{g}^{-1} \mathrm{C}$ & 4811 & 465 & 2742 & 186 & 3961 & 75 \\
Zeax & $\mathrm{nmol} \mathrm{g}^{-1} \mathrm{C}$ & 370 & 43 & 222 & 36 & 974 & 43 \\
Bchl a & $\mathrm{nmol} \mathrm{g}^{-1} \mathrm{C}$ & 971 & 203 & 91 & 28 & 1214 & 137 \\
Bphea & $\mathrm{nmol} \mathrm{g}^{-1} \mathrm{C}$ & 151 & 36 & $\mathrm{nd}$ & - & 164 & 8 \\
Bcar & $\mathrm{nmol} \mathrm{g}^{-1} \mathrm{C}$ & 21 & 4 & 14 & 3 & 47 & 13 \\
Bact & $\mathrm{nmol} \mathrm{g}^{-1} \mathrm{C}$ & 650 & 151 & 641 & 204 & 1363 & 146 \\
\hline
\end{tabular}

along with their respective biomass concentrations. Total photosynthetic pigment concentrations were highest, intermediate and lowest for E. longus Strain NJ3Y grown under the 0:24, 12:12 and 24:0 h L:D regimes, respectively. While total photosynthetic pigment levels were relatively constant during the 24:0 and 0:24 h L:D regimes, total photosynthetic pigment concentration varied temporally during the 12:12 $\mathrm{h}$ L:D cycle experiment $(\mathrm{CV}=18.7 \%)$, with the highest synthesis rates occurring in the dark. In comparison, caloxanthin sulfate concentrations during the 12:12 h L:D cycle were relatively constant $(\mathrm{CV}=$ $9.7 \%)$. light (0.71) and all dark (0.51) cultures than for the 12:12 h L:D cycle (0.38). The RQ ( $\mathrm{mol} \mathrm{mol}^{-1}$ ), which represents the ratio of $\mathrm{CO}_{2}$ evolution rate to the $\mathrm{O}_{2}$ uptake rate, was close to unity for all treatments. This result indicates negligible levels of carbon dioxide fixation for all light regimes. Although not presented in Tables 1 or 2 , the transient nature of the time-series data is summarized below. For growth under the 24:0 $\mathrm{h}$ and 0:24 $\mathrm{h}$ L:D regimes, no measurable timedependent trends were observed for any of the variables. In contrast, time-dependent trends were observed for E. longus Strain NJ3Y grown under a 12:12 h L:D cycle. In particular, biomass yields and $\mathrm{C}: \mathrm{N}$ ratios were highest in the light and lowest in the dark. Carbon-specific glucose uptake rates were highest at the beginning of the $12 \mathrm{~h}$ light cycle and decreased to a plateau below the average at the end of the $12 \mathrm{~h}$ dark cycle.

Caloxanthin sulfate concentrations were different for each of the 3 light treatments, with highest, intermediate and lowest values for the 12:12, 0:24 and 24:0 h L:D regimes, respectively (Tukey's pairwise comparison, family error rate $=0.05$; Table 2 ). In contrast, zeaxanthin and Bchl a concentrations were highest, intermediate and lowest for Erythrobacter longus Strain NJ3Y grown under the 0:24, 12:12 and 24:0 h L:D regimes, respectively (Tukey's pairwise comparison, family error rate $=0.05$ ). A statistically different pattern was observed for the other photosynthetic pigments of E. longus Strain NJ3Y (bacteriorubixanthinal and $\beta, \beta$-carotene), with highest concentrations in the 0:24 h L:D treatment and lower (and statistically identical) values in the 12:12 and 24:0 h L:D regimes. Time-dependent variations in the carbon-specific total photosynthetic pigment concentrations for the 3 light regimes are shown in Fig. 2
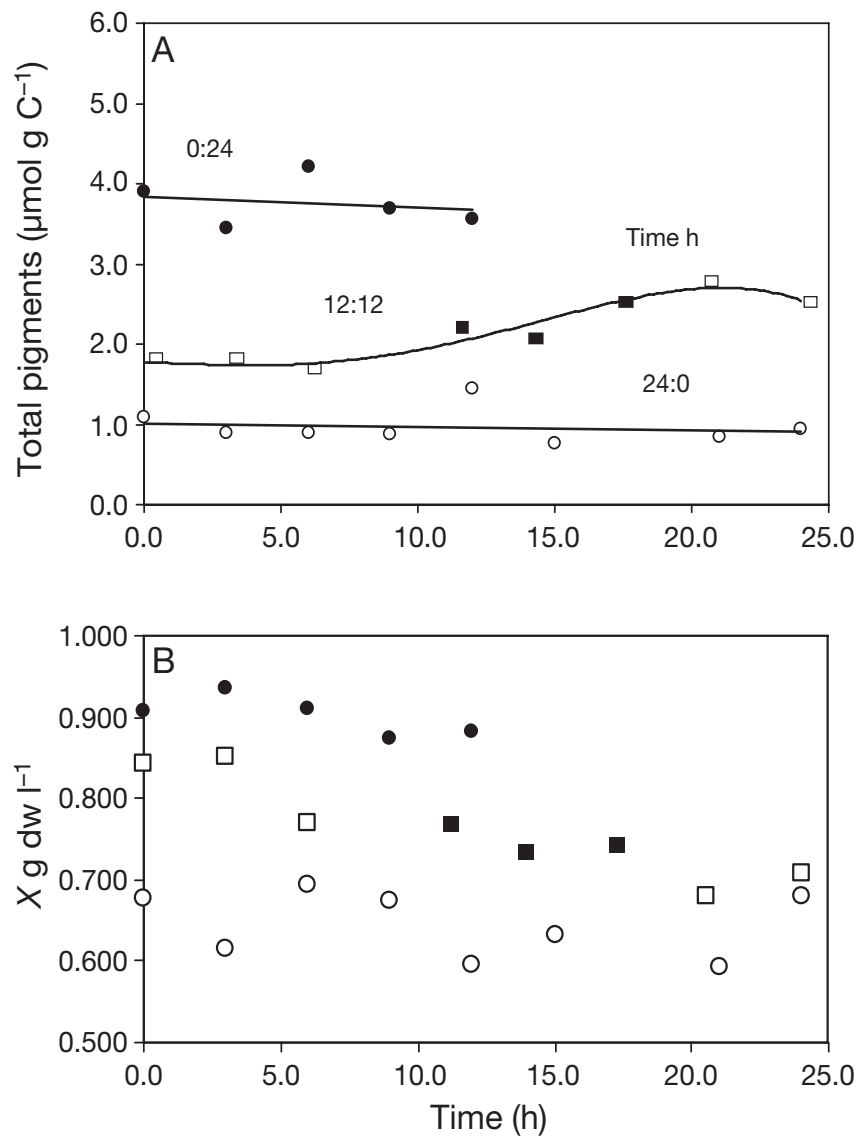

Fig. 2. Erythrobacter longus Strain NJ3Y. Time-series of total carbon-specific photosynthetic pigments for continuous cultures maintained on light:dark cycles of $12: 12 \mathrm{~h}(\square, \mathbf{\square} ; 4$ th order polynomial fit), 24:0 h (O; linear fit) and 0:24 h (- linear fit). Time zero represents commencement of light cycling after the culture had been established at steady state for at least 3 residence times. $\mathbf{\square}$ : time points in continous darkness; $\square$ : time points during light mode. (B) Time-dependent biomass concentrations. $X$ : dry cell weight 


\section{DISCUSSION}

The present study focused on inter-regime comparisons between all light, all dark and the 12:12 h L:D light treatments. Although Erythrobacter longus Clone NJ3Y has previously been shown to exhibit a dynamic reduction in respiration at the onset of illumination (Kobližek et al. 2003), this was not observed in the present study. More specifically, during a previous investigation of carbon mass balancing as applied to continuous cultures of pigmented marine bacteria, it was determined that the ability to detect lightinduced metabolic transients was limited (Johnston et al. 2005). This is attributed to the uncertainties associated with the calculation of respiration rates using a reduction balance approach, in combination with buffering of carbon dioxide release by the carbonate system present in seawater growth medium (Johnston et al. 2005).

Significant differences in pigmentation were observed between the experimental light treatments. Highest carbon-specific photosynthetic pigment concentrations (i.e. zeaxanthin, Bchl $a$, bacteriopheophytin $a, \beta, \beta$-carotene and bacteriorubixanthinal) were observed for Erythrobacter longus Strain NJ3Y grown under complete darkness (Table 2). Lowest Bchl a, bacteriopheophytin $a$ and zeaxanthin concentrations were measured for cells grown under continuous illumination. These findings reveal that the measured photosynthetic pigments of $E$. longus Clone NJ3Y were preferentially synthesized in the dark; $\beta, \beta$ carotene and bacteriorubixanthinal concentrations observed for the 12:12 and 24:0 h L:D regimes were not statistically different (Tukey's pairwise comparison, family error rate $=0.05$ ). This pattern is also evident in the time-series of total photosynthetic pigment concentration presented in Fig. 2.

These trends are consistent with the strategy of producing photosynthetic pigments during periods of darkness, for use in energy harvesting during subsequent light periods (Koblížek et al. 2003). In contrast, concentrations of the photoprotective pigment caloxanthin sulfate were highest for cells grown under a 12:12 h L:D cycle, indicating that this carotenoid is synthesized in the light and the dark. A decoupling of photosynthetic and photoprotective pigment synthesis was previously observed for the type strain of Erythrobacter longus (ATCC 33941) by Shimada et al. (1985). It is concluded that the $12: 12 \mathrm{~h} \mathrm{~L}: \mathrm{D}$ regime provides the maximum opportunity for E. longus Strain NJ3Y to derive a metabolic advantage from light availability (i.e. by enabling it to both synthesize and utilize its light harvesting apparatus). The corresponding carbon-specific glucose uptake rate was $\sim 30 \%$ higher than that measured for the $0: 24$ and $24: 0 \mathrm{~h} \mathrm{~L}: \mathrm{D}$ regimes. It is hypothesized that light-stimulated rates of DOC uptake by Bchl a containing bacteria confer a slight competitive advantage over bacteria that lack this photosynthetic machinery.

It is interesting to compare our results with those obtained for the freshwater APP Erythromicrobium hydrolyticum grown in continuous culture at similar dilution rates (0.08 vs. $0.09 \mathrm{~h}^{-1}$ in the present study) under a 14:10 h L:D cycle (Yurkov \& van Gemerden 1993). Yurkov \& van Gemerden (1993) also found the concentration of Bchl a to be lower in illuminated cultures compared to cultures maintained in continous darkness (11 to 22 vs. 230 to $241 \mathrm{nM}$ ). Similarly, they found that a shift from darkness to light increased biomass formation, suggesting that photosynthesis contributes to the grow rate of E. hydrolyticum. In contrast, our results did not confirm their findings that light cycling (L:D regime) results in enhanced rates of biomass formation. We found that cultures grown in continous darkness had a greater biomass concentration (both dry cell weight $X$ and carbon-specific $C_{\mathrm{x}}$ ) than cells grown under a 12:12 h L:D cycle. In addition, the lowest glucose-specific biomass yields $\left(Y_{\mathrm{x} / \mathrm{s}}, \mathrm{g} \mathrm{dcw}^{-1}\right.$ glucose) were also observed for the 12:12 h L:D treatment, suggesting that under the culture conditions used in our study, photosynthesis does not contribute significantly to the growth of Erythrobacter longus Strain NJ3Y. Furthermore, this implies that the growth efficiency of AAP bacteria would be lower when using light energy to supplement energy from organic carbon oxidation. Similar findings were reported for the PR containing Pelagibacter ubique (SAR11 Strain HTCC1062) by Giovannoni et al. (2005b), who found no difference between the growth rates or cell yields of cultures grown in light or darkness. Light manipulation experiments and environmental DNA sequencing of seawater samples collected in mesotrophic and oligotrophic waters off California revealed that representatives of the SAR86, SAR11 and SAR116 clades of $P$. ubique displayed small and mixed responses to light removal, indicating that only a few select members may benefit from a photoheterotrophic metabolism (Schwalbach et al. 2005). It is concluded that additional research is needed to determine whether Bchl $a$ and PR genes provide an alternative ecological benefit (Schwalbach et al. 2005) or whether the negative findings summarized above result from our inability to reproduce natural conditions in experimental studies (Giovannoni et al. 2005b).

Acknowledgements. This research was supported by NSF grant EED-9731725 to M.J.C. and R.R.B. and NSF grant OCE0326616 to R.R.B. The authors acknowledge the contributions of P. G. Falkowski and Z. S. Kolber in providing Strain NJ3Y and experimental advice, and Stephanie Christensen for technical help with biochemical analyses. 


\section{LITERATURE CITED}

Beatty JT (2002) On the natural selection and evolution of the aerobic phototrophic bacteria. Photosynth Res 73:109-114

Béjà O, Aravind L, Koonin EV, Suzuki MT and 8 others (2000) Bacterial rhodopsin: evidence for a new type of phototrophy in the sea. Science 289:1902-1906

Béjà O, Spudich EN, Spudich JL, Leclerc M, DeLong EF (2001) Proteorhodopsin phototrophy in the ocean. Nature 411:786-789

Béjà O, Suzuki MT, Heidelberg JF, Nelson WC and 5 others (2002) Unsuspected diversity among marine aerobic anoxygenic phototrophs. Nature 415:630-633

Bidigare RR, Van Heukelem L, Trees CC (2005) Analysis of algal pigments by high-performance liquid chromatography. In: Andersen RA (ed) Culturing methods and growth measurements. Academic Press, New York, p 327-345

Church M, Ducklow H, Karl DM (2002) Multi-year increases in dissolved organic matter inventories at Station ALOHA in the North Pacific Subtropical Gyre. Limnol Oceanogr 47:1-10

Cottrell MT, Mannino A, Kirchman DL (2006) Aerobic anoxygenic phototrophic bacteria in the Mid-Atlantic Bight and the North Pacific Gyre. Appl Environ Microbiol 72: 557-564

de la Torre JR, Christianson LM, Béjà O, Suzuki MT, Karl DM, Heidelberg J, DeLong EF (2003) Proteorhodopsin genes are distributed among divergent marine bacterial taxa. Proc Natl Acad Sci USA 100:12830-12835

DeLong EF, Karl DM (2005) Genomic perspectives in microbial oceanography. Nature 437:336-342

DeLong EF, Preston CM, Mincer T, Rich V and 8 others (2006) Community genomics among stratified microbial assemblages in the ocean's interior. Science 311:496-503

Fenchel T (2001) Marine bugs and carbon flow. Science 292: $2444-2445$

Giovannoni SJ, Sting U (2005) Molecular diversity and ecology of microbial plankton. Nature 437:343-348

Giovannoni SJ, Tripp HJ, Givan S, Podar M and 10 others (2005a) Genome streamlining in a cosmopolitan oceanic bacterium. Science 309:1242-1245

Giovannoni SJ, Bibbs L, Cho JC, Stapels MD and 7 others (2005b) Proteorhodopsin in the ubiquitous marine bacterium SAR11. Nature 438:82-85

Goericke R (2002) Bacteriochlorophyll $a$ in the ocean: is anoxygenic bacterial photosynthesis important? Limnol Oceanogr 47:290-295

Harashima K, Shiba T, Totsuka T, Simidu U, Taga N (1978) Occurrence of bacteriochlorophyll $a$ in a Strain of an aerobic heterotrophic bacterium. Agric Biol Chem 42: 1626-1628

Jiao N, Zhang Y, Du Hailian, Zeng Y, Hong N, Hu Y (2005) Dual niche of anoxygenic phototrophic bacteria in the ocean. 2005 International Ocean Research Conference (6-10 June, Paris), p 97

Johnston WA, Cooney MJ, Schorlemmer A, Pohl S, Karl DM, Bidigare RR (2005) Carbon mass balance methodology to characterize the growth of pigmented marine bacteria under conditions of light cycling. Bioprocess Biosyst Eng $27: 163-174$

Editorial responsibility: William K. W. Li,

Dartmouth, Nova Scotia, Canada
Karl DM (2002) Hidden in a sea of microbes. Nature 415: 590-591

Koblížek M, Béjà O, Bidigare RR, Christensen S, BenitezNelson B, Vetriani C, Falkowski PG (2003) Isolation and characterization of Erythrobacter sp. Strains from the upper ocean. Arch Microbiol 180:327-338

Kolber ZS, Van Dover CL, Niederman RA, Falkowski PG (2000) Bacterial photosynthesis in surface waters of the open ocean. Nature 407:177-179

Kolber ZS, Plumley FG, Lang AS, Beatty JT and 6 others (2001) Contribution of aerobic photoheterotrophic bacteria to the carbon cycle in the ocean. Science 292:2492-2495

Morris RM, Rappé MS, Connon SA, Vergin KL, Siebold WA, Carlson CA, Giovannoni SJ (2002) SAR11 clade dominates ocean surface bacterioplankton communities. Nature 420 : 806-810

Nielsen J, Villadsen J (1994) Bioreaction engineering principles. Plenum Press, New York

Rappé MS, Connon SA, Vergin KL, Giovannoni SJ (2002) Cultivation of the ubiquitous SAR11 marine bacterioplankton clade. Nature 418:630-633

Rathgeber C, Beatty JT, Yurkov (2004) Aerobic phototrophic bacteria: new evidence for the diversity, ecological importance and applied potential of this previously overlooked group. Photosynth Res 81:113-128

Schwalbach MS, Furhman JA (2005) Wide-ranging abundances of aerobic anoxygenic phototrophic bacteria in the world ocean revealed by epifluorescence microscopy and quantitative PCR. Limnol Oceanogr 50:620-628

Schwalbach MS, Brown M, Fuhrman JA (2005) Impact of light on marine bacterioplankton community structure. Aquat Microb Ecol 39:235-245

Shiba T, Simidu U, Taga N (1979) Distribution of aerobic bacteria which contain bacteriochlorophyll a. Appl Environ Microbiol 38:43-48

Shiba T, Shioi Y, Takamiya KI, Sutton DC, Wilkinson CR (1991) Distribution and physiology of aerobic bacteria containing bacteriochlorophyll $a$ on the east and west coasts of Australia. Appl Environ Microbiol 57:295-300

Shimada K, Hayashi H, Tasumi M (1985) Bacteriochlorophyll-protein complexes of aerobic bacteria, Erythrobacter longus and Erythrobacter species OCH 114. Arch Microbiol 143:244-247

Venter CJ, Remington K, Heidelberg JF, Halpern AL and 19 others (2004) Environmental genome shotgun sequencing of the Sargasso Sea. Science 304:66-74

Waidner LA, Kirchman DL (2005) Aerobic anoxygenic photosynthesis genes and operons in uncultured bacteria in the Delaware River. Environ Microbiol 7:1896-1908

Yurkov VV, Beatty JT (1998) Aerobic anoxygenic phototrophic bacteria. Microbiol Mol Biol Rev 62:695-724

Yurkov VV, van Gemerden H (1993) Impact of light/dark regime on growth rate, biomass formation, and bacteriochlorophyll synthesis in Erythromicrobium hydrolyticum. Arch Microbiol 159:84-89

Yurkov VV, Gad'on N, Drews G (1993) The major part of polar carotenoids of the aerobic bacteria Roseococcus thiosulfatophilus RB3 and Erythromicrobium ramosum E5 is not bound to the bacteriochlorophyll a-complexes of the photosynthetic apparatus. Arch Microbiol 160:372-376

Submitted: September 19, 2005; Accepted: April 18, 2006

Proofs received from author(s): July 5, 2006 